\title{
HUBUNGAN LAYANAN ORIENTASI DENGAN PENYESUAIAN DIRI SISWA KELAS X SMA SWASTA TAMAN SISWA BINJAI TAHUN PELAJARAN 2017/2018
}

\author{
M. Dian Wahyudi \\ Dosen STKIP Budidaya Binjai
}

\begin{abstract}
Abstrak
Tujuan penelitian untuk mengetahui hubungan layanan orientasi dengan penyesuaian diri siswa di SMA Swasta Taman Siswa Binjai. Populasi penelitian seluruh siswa kelas X di SMA Swasta Taman Siswa Binjai sebanyak 120 siswa orang. Dengan jumlah sampel dalam penelitian ini adalah sebanyak 30 orang. Hasil penelitian diperoleh kesimpulan bahwa terdapat hubungan antara pelaksanaan layanan orientasi dengan penyesuaian diri siswa sebesar $r x y=0,605$, tingkat hubungan ini termasuk pada interval tingkat hubungansedang. Hasil pengujian ini membuktikan bahwa pelaksanaan layanan orientasi dengan penyesuaian diri siswa di SMA Swasta Taman Siswa Kota Binjai memiliki kaitan yang signifikan yang berarti bahwa baiknya penyesuaian diri siswa di dukung oleh pelaksanaan layanan orientasi yang dilakukan guru pembimbing di sekolah.
\end{abstract}

kata kunci: layanan orientasi, penyesuaian diri siswa

\section{PENDAHULUAN}

Pendidikan merupakan salah satu bentuk lingkungan yang bertanggung jawab dalam proses perkembangan individu (siswa). Bimbingan dan Konseling merupakan salah satu aspek dalam pendidikan. Bimbingan dan konseling merupakan bantuan terhadap individu dalam memperoleh penyesuaian diri sesuai dengan tingkat perkembangannya. Perkembangan dapat dilihat dalam pendidikan atau sekolah. Sesuai dengan kebijaksanaan pemerintah, pendidikan diartikan sebagai suatu usaha sadar untuk mengembangkan kepribadian yang berlangsung di sekolah maupun di luar sekolah dan berlangsung seumur hidup. Hasil pendidikan individu terletak pada sejauh mana yang dipelajari dapat membantunya dalam menyesuaikan diri dengan kebutuhan-kebutuhan hidupnya dan pada tuntutan masyarakat.

Pendidikan juga merupakan suatu proses dalam rangka mempengaruhi siswa agar dapat menyesuaikan diri sebaik mungkin terhadap lingkungannya dan dengan demikian akan menimbulkan perubahan dalam dirinya yang memungkinkan untuk berfungsi secara kuat dalam kehidupan masyarakat. Sedangkan pengajaran bertugas mengarahkan proses ini agar sasaran dari perubahan itu dapat tercapai sebagai mana yang diinginkan. Menurut UU Nomor 20 tahun 2003, pendidikan adalah usaha sadar dan terencana untuk mewujudkan suasana belajar dan proses pembelajaran agar peserta didik secara aktif mengembangkan 
potensi dirinya untuk memiliki kekuatan spiritual keagamaan, pengendalian diri, kepribadian, kecerdasan, akhlak mulia, serta keterampilan yang diperlukan dirinya, masyarakat, bangsa dan Negara.

Berdasarkan penjelasan tersebut, maka pendidikan tidak terlepas dari istilah membimbing atau memberikan bimbingan. Nurihasan (2006:5) mengungkapkan pendidikan yang bermutu mengacu pada kemampuan lembaga pendidikan dalam mengintegrasikan, mendistribusikan, mengelola, dan mendayagunakan sumber-sumber pendidikan secara optimal sehingga dapat meningkatkan kemampuan belajar lulusannya. Pendidikan yang hanya melaksanakan bidang administratif dan pengajaran dengan mengabaikan bidang bimbingan dan konseling mungkin hanya akan menghasilkan individu yang pintar dan terampil dalam aspek akademik, tetapi kurang memiliki kematangan dalam aspek psiko-sosio-spiritual.

Berkaitan dengan memberi bantuan kepada siswa yang memiliki masalah tentang penyesuaian dirinya, salah satu layanan yang dapat diberikan adalah layanan orientasi, karena dalam kegiatan layanan orientasi tersebut siswa dapat berinteraksi dan berkomunikasi antar sesama anggota kelompok. Layanan orientasi merupakan salah satu jenis layanan dalam bimbingan dan konseling yang bertujuan untuk memberikan pemahaman kepada siswa. Melalui layanan orientasi memungkinkan siswa menerima dan memahami berbagai sesuatu yang dapat dipergunakan sebagai bahan pertimbangan dan pengambilan keputusan untuk kepentingan dirinya. Dengan kata lain layanan orientasi adalah layanan yang diberikan untuk membekali individu dengan berbagai hal yang berguna untuk mengenal diri, merencanakan dan mengembangkan pola kehidupan sebagai pelajar, anggota keluarga dan masyarakat Masa remaja dikatakan sebagai masa peralihan antara masa anak ke masa dewasa.

Dilihat dari proses dan fase perkembangannya, para siswa termasuk siswa SMA beradapada masa remaja (adolescent). Masa ini ditandai dengan berbagai perubahan menuju kearah tercapainya kematangan dalam berbagai aspek seperti biologis, intelektual, emosional,

sikap nilai, dan sebagainya. Dalam situasi ini siswa akan mengalami berbagai guncangan yang akan mempengaruhi seluruh pola perilakunya, dan secara langsung atau tidaklangsung mempengaruhi proses belajarnya. Sesuai dengan perkembangannya, remaja 
dituntut lebih belajar menyesuaikan diri dengan lingkungan sosial yang lebih luas dan majemuk. Proses penyesuaian diri ini banyak sekali menimbulkan berbagai masalah terutama bagi diri siswa sendiri sebagai individu. Jika individu dapat berhasil memenuhi kebutuhan lingkungan sesuai dengan lingkungannya dan tanpa menimbulkan gangguan atau kerugian bagi lingkungannya, hal ini disebut adjusted atau penyesuaian yang baik. Sebaliknya jika individu gagal dalam proses penyesuaian diri tersebut, disebutmaladjusted atau penyesuaian yang yang salah. Dalam hal ini, sekolah hendaknya memberikan bantuan agar setiap siswa dapat menyesuaikan diri dengan baik dan terhindar dari timbulnya gejalagejala penyesuaian diri yang salah, seperti tingkah laku agresif, rasa rendah diri, bersikap bandel, haus perhatian, mencuri dan sebagainya.

Apabila individu gagal dalam memperoleh penyesuaian diri, maka ia akan sampai pada suatu situasi penyesuaian yang salah. Gejala-gejala penyesuaian yang salah ini akan dimanifestasikan dalam bentuk tingkah laku yang kurang wajar atau yang sering disebut bentuk tingkah laku yang tidak baik. Sampai tingkat tertentu, siswa Taman Siswa yang telah memasuki masa remaja lebih suka menonjolkan diri. Masa remaja sebagai masa transisi (peralihan) dari masa anak-anak menuju masa dewasa. Seiring dengan itu, mereka berada dalam kebimbangan dan kebingungan, dan tidak begitu percaya diri.

Tingkah laku atau kegiatan yang dilakukan seseorang termasuk siswa sebagai remaja pada hakikatnya merupakan cara pemenuhan kebutuhan. Banyak cara yang dapat ditempuh individu untuk memenuhi kebutuhannya, baik cara-cara yang wajar maupun yang tidak wajar, cara-cara yang disadari maupun yang tidak disadari. Untuk dapat memenuhi kebutuhan ini, individu harus dapat menyesuaikan diri antara kebutuhan dengan segala kemungkinan yang ada dalam lingkungannya, atau disebut dengan proses penyesuain diri. Individu harus menyesuaikan diri dengan berbagai lingkungan, baik lingkungan sekolah, rumah, maupun masyarakat. Kenyataannya, gejala-gejala semacam ini sering kali banyak menimbulkan berbagai masalah. Tentu saja hal itu tidak dapat dibiarkan terus, karena akan banyak mengganggu, baik bagi individu itu sendiri maupun bagi lingkungannya. Oleh karena itu diperlukan adanya suatu usaha nyata untuk menanggulangi gejala-gejala tersebut. Maka bimbingan dan konseling memberikan peranan yang cukup penting. 
Berdasarkan hasil pengamatan terhadap kondisi objektif siswa di SMA Swasta Taman Siswa Binjai, peneliti menemukan bahwa siswa di SMA Taman Siswa ini sangatlah beragam dari berbagai daerah, suku, tingkat ekonomi, kepribadian dan lain sebagainya. Keberagaman siswa di sekolah ini dapat sebagai penyebab terjadi beberapa permasalahan yang menyangkut prilaku siswa, terutama perilaku kemampuan dalam menyesuaikan diri dalam lingkungan sekolah. Dari beberapa siswa diketahui hanya bergaul dengan sesama mereka saja dan terasing dari kelompok lainnya, siswa kurang mampu dalam melakukan penyesuaian diri di lingkungan sekolahnya sehingga kurang mampu melakukan hubungan dengan teman lainnya dan dengan guru di sekolah. Keadaan yang terjadi pada siswa ini terkait dengan masih kurang optimalnya pelaksanaan layanan orientasi yang diberikan kepada siswa.

Guru pembimbing kurang maksimal dalam melaksanakan layanan orientasi yang mendukung terhadap kemampuan siswa agar lebih mampu dalam menyesuaikan diri terutama di lingkungan sekolah. Kondisi di atas harus ditanggapi oleh guru pembimbing di sekolah terutama memberikan layanan orientasi. Layanan orientasi yang diberikan merupakan wahana untuk menambah pemahaman, penerimaan diri dan orang lain, menemukan alternatif cara penyelesaian masalah, mengambil keputusan yang tepat dari konflik yang dialami dan untuk meningkatkan rasa tanggung jawab pada diri sendiri dan orang lain. Demikian pentingnya layanan orientasi dalam pembinaan penyesuaian diri siswa, sehingga penulis merasa termotivasi untuk melakukan suatu penelitian dengan mengangkat judul: Hubungan Layanan Orientasi dengan Penyesuaian Diri Siswa Kelas X SMA Swasta Taman Siswa Binjai Tahun Pelajaran 2017/2018.

\section{METODE}

Penelitian ini akan dilaksanakan di SMA Swasta Taman Siswa Binjai yang berlokasi Kota Kota Binjai. Penelitian ini dilaksanakan pada semester I Tahun Pelajaran 2013/2014. Kegiatan penelitian direncanakan dimulai pada bulan September dan berakhir pada bulan Nopember 2013.

Populasi dalam penelitian ini adalah seluruh siswa kelas X di SMA Swasta Taman Siswa Binjai sebanyak 120 siswa orang. Sampel penelitian ditentukan sejumlah $25 \%$ dari populasi yaitu berjumlah 30 orang. 
Data yang diperoleh dalam penelitian dianalisis secara deskriptis, yaitu melalui tabel frekuensi tabulasi berdasarkan karakteristik data. Analisis deskriptif bertujuan untuk menyajikan data sesuai dengan keadaan sebenarnya kemudian menginterpretasikannya untuk menjawab permasalahan penelitian. Selanjutnya untuk mengetahui hubungan pelaksanaan layanan orientasi dengan peningkatan disiplin siswa, dilakukan analisis statistik. Menurut Arikunto (2009:251), untuk penelitian dengan tujuan menemukan ada tidaknya hubungan antara variabel, maka metode analisis data adalah korelasi produck moment, dengan rumus:

$$
r_{X Y}=\frac{n \sum x y-\left(\sum x\right)\left(\sum y\right)}{\sqrt{\left(n \sum x^{2}-\left(\sum x\right)^{2}\right)\left(n \sum y^{2}-\left(\sum y\right)^{2}\right)}}
$$

\section{PEMBAHASAN}

\section{Temuan Penelitian}

Dari perhitungan diperoleh korelasi antara pelaksanaan layanan orientasi dengan penyesuaian diri siswa sebesar $\mathrm{rxy}=0,605$, tingkat hubungan ini termasuk pada interval tingkat hubungan sedang. Untuk mengetahui apakah korelasi antara variabel pelaksanaan layanan orientasi dengan variabel penyesuaian diri siswa diterima atau tidak maka nilai rhitung tersebut dibandingkan dengan nilai rtabel. Nilai rtabel untuk $n=30$ dan taraf signifikansi $\alpha=5 \%$ adalah 0,361. Didapat nilai rhitung > nilai rtabel atau 0,605 >0,361, maka dapat disimpulkan pelaksanaan layanan orientasi memiliki hubungan yang signifikan dengan penyesuaian diri siswa di SMA Swasta Taman Siswa Kota Binjai Tahun Pelajaran 2013/2014.

Untuk melihat tingkat signifikan antara kedua variabel di atas maka dapat digunakan rumus Uji " $\mathrm{t}$ " dan diperoleh thitung $=4,0219$. Dengan hasil thitung di atas maka dapat dikatakan hubungan antara pelaksanaan layanan orientasi dengan penyesuaian diri siswa di SMA Swasta Taman Siswa Kota Binjai memiliki kaitan yang signifikan karena thitung > ttabel $(4,0219>1,680)$. Untuk melihat persentase hubungan ini maka dapat digunakan rumus koefesien determinan dan diperoleh $\mathrm{KP}=36,62 \%$. Dengan demikian, dapat dinyatakan sebesar 36,62\% penyesuaian diri siswa di SMA Swasta Taman Siswa Kota Binjai dipengaruhi oleh pelaksanaan layanan orientasi dan sisanya sebesar $63,38 \%$ ditentukan faktor lainnya. 


\section{Pembahasan}

Berdasarkan hasil penelitian di atas membuktikan bahwa adanya kaitan yang positif antara pelaksanaan layanan orientasi dengan penyesuaian diri siswa di SMA Swasta Taman Siswa Kota Binjai. Dari hasil uji korelasi antara pelaksanaan layanan orientasi dengan penyesuaian diri siswa pada taraf signifikansi $\alpha=5 \%$ adalah 0,605 . Nilai rhitung $>$ nilai rtabel atau 0,605 >0,361, dan berdasarkan hasil thitung di peroleh thitung $>$ ttabel $(4,0219>1,680)$. Hasil pengujian di atas membuktikan bahwa antara pelaksanaan layanan orientasi dengan penyesuaian diri siswa di SMA Swasta Taman Siswa Kota Binjai memiliki kaitan yang signifikan yang berarti bahwa baiknya penyesuaian diri siswa didukung oleh pelaksanaan layanan orientasi yang dilakukan guru pembimbing di sekolah.

Dalam proses pembelajaran siswa perlu arahan dari pihak sekolah, terutama dari guru pembimbimng. Arahan yang diberikan tentunya akan ditanggapi siswa sebagai perwujudan sikap terhadap pelaksanaan proses pembelajaran tersebut. Tanggapan siswa ini adalah kecenderungan untuk merespon dengan cara yang khusus terhadap stimulus yang ada dalam lingkungan belajar mengajar yang dilaksanakan. Pelaksanaan layanan orientasi yang tepat adalah untuk mengarahkan siswa agar aktif melakukan berbagai aktivitas yang diberikan oleh guru kepadanya. Sebagai wujud aktivitas belajar yang baik dilakukan oleh siswa adalah keberhasilannya dalam belajar. Keberasilan belajar ini dibuktikan dengan perolehan hasil belajar yang baik. Untuk memperoleh prestasi atau hasil belajar yang baik tentunya tidak selalu mudah. Hal ini dikarenakan banyak faktor yang harus diperhatikan sebagai pendukung terhadap keberhasilan dalam penyesuaian diri yang lebih baik. Berdasarkan uraian di atas dapat dipahami bahwa pelaksanaan layanan orientasi dapat membantu siswa untuk lebih mudah dalam menerima dan memahami dirinya sehingga siswa lebih mampu dalam melakukan penyesuaian diri di sekolah.

\section{SIMPULAN}

1. Pelaksanaan layanan orientasi kepada siswa di SMA Swasta Taman Siswa Kota Binjai dapat dilaksanakan dengan baik sesuai dengan pedoman pelaksanaan penyelenggaraan layanan orientasi di sekolah. Adapun pelaksanaan kegiatan layanan orientasi yaitu dengan melakukan tahapan-tahapan yang terdiri dari (a) perencanaan kegiatan layanan 
orientasi, (b) pelaksanaan/operasional kegiatan, (c) evaluasi pelaksanan layanan orientasi, (d) analisa hasil evaluasi, (e) tindak lanjut, dan (f) pelaporan hasil kegiatan.

2. Penyesuaian diri siswa di SMA Swasta Taman Siswa Kota Binjai dapat dilaksanakan dengan baik, dalam hal ini siswa mampu melaksanakan (a) pengembangan diri pribadi, (b) proses belajar, (c) pendidikan lanjutan, dan (d) pengembagan kehidupan berkeluarga dan masyarakat.

3. Hasil perhitungan di atas didapat bahwa korelasi antara pelaksanaan layanan orientasi dengan penyesuaian diri siswa sebesar $r x y=0,605$, tingkat hubungan ini termasuk pada interval tingkat hubungan sedang. Hasil pengujian ini membuktikan bahwa pelaksanaan layanan orientasi dengan penyesuaian diri siswa di SMA Swasta Taman Siswa Kota Binjai memiliki kaitan yang signifikan yang berarti bahwa baiknya penyesuaian diri siswa di dukung oleh pelaksanaan layanan orientasi yang dilakukan guru pembimbing di sekolah.

\section{REFERENSI}

Ali, Mohammad dan Mohammad Asrori. 2005. Psikologi Remaja, Perkembangan Peserta Didik. Jakarta: Bumi Aksara

Arikunto, Suharsimi. 2009. Prosedur Penelitian Suatu Pendekatan Praktek. Jakarta: Rineka Cipta

Departemen Pendidikan dan Kebudayaan. 1996. Kurikulum Menengah Umum: Petunjuk Pelaksanaan Bimbingan dan Konseling. Jakarta: Departemen Pendidikan dan Kebudayaan

Gunawan. Yusuf. 2001. Pengantar Bimbingan dan Konseling. Jakarata: Prenhallindo

Hallen A. 2002. Bimbingan dan Konseling. Jakarta: Ciputat Pers

Kartadinata. Sunaryo. 1998. Bimbingan di Sekolah Dasar. Bandung: Maulana

Luddin. Abu Bakar M. 2010. Dasar-Dasar Konseling Tinjauan Teori dan Praktik. Bandung: Cita Pustaka Media Perintis

Nurihsan, Ahmad Juntika. 2006. Bimbingan dan Konseling Dalam Berbagai Latar Kehidupan. Bandung: Refika Aditama

Prayitno dan Erman Amti. 1999. Dasar-Dasar Bimbingan dan Konseling. Jakarta: Proyek 
Pembinaan dan Peningkatan Mutu Tenaga Kependidikan Direktoral Jenderal

Pendidikan Tinggi Depertemen Pendidikan Dan Kebudayaan Salim. Suradi. 1996.

Bimbingan dan Konseling. Kuala Lumpur: Percetakan Semarak .

Shertzer, Bruce dan Stone Shelley. 1997. Fundamental of Guidance. New York: Hougton Mifflin Company

Undang-Undang Republik Indonesia No 20 Tahun 2003 tentang Sistem Pendidikan Nasional.

WS. Winkel. 1997. Bimbingan dan Konseling di Institusi Pendidikan. Jakarta: Gramedia Widiasarana Indonesia 